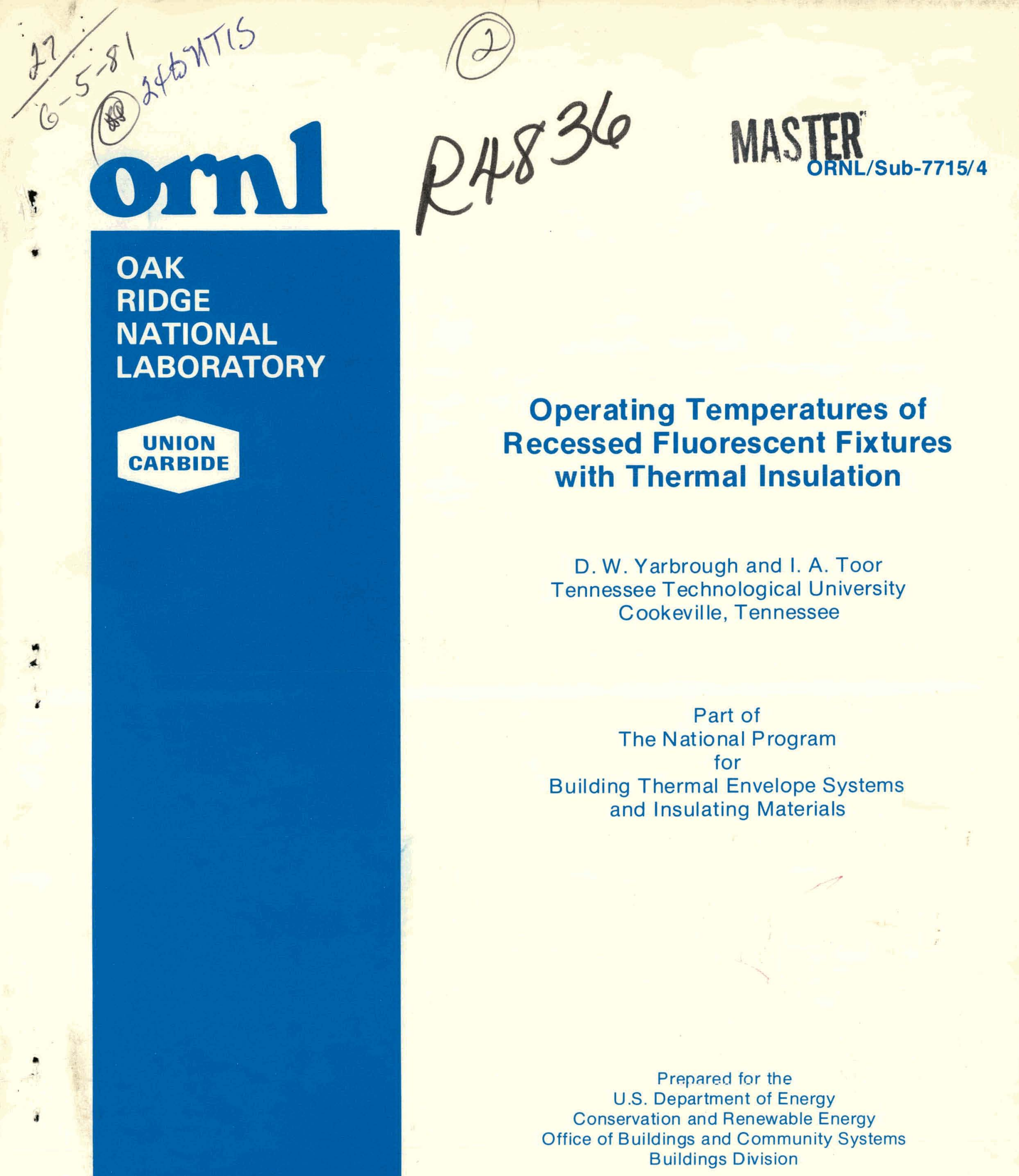

OPERATED BY

UNION CARBIDE CORPORATION

FOR THE UNITED STATES

DEPARTMENT OF ENERGY 


\section{DISCLAIMER}

This report was prepared as an account of work sponsored by an agency of the United States Government. Neither the United States Government nor any agency Thereof, nor any of their employees, makes any warranty, express or implied, or assumes any legal liability or responsibility for the accuracy, completeness, or usefulness of any information, apparatus, product, or process disclosed, or represents that its use would not infringe privately owned rights. Reference herein to any specific commercial product, process, or service by trade name, trademark, manufacturer, or otherwise does not necessarily constitute or imply its endorsement, recommendation, or favoring by the United States Government or any agency thereof. The views and opinions of authors expressed herein do not necessarily state or reflect those of the United States Government or any agency thereof. 


\section{DISCLAIMER}

Portions of this document may be illegible in electronic image products. Images are produced from the best available original document. 


\section{Printed in the United States of America. Available from National Technical Information Service \\ U.S. Department of Commerce 5285 Port Royal Road, Springfield, Virginia 22161 NTIS price codes-Printed Copy: A03 Microfiche A01}

This report was prepared as an account of work sponsored by an agency of the United States Government. Neither the United States Government nor any agency thereof, nor any of their employees, makes any warranty, express or implied, or assumes any legal liability or responsibility for the accuracy, completeness, or usefulness of any information, apparatus, product, or process disclosed, or represents that its use would not infringe privately owned rights. Reference herein to any specific commercial product, process, or service by trade name, trademark, manufacturer, or ullierwlse, dues ruol necessarily cuistilute vi imply its endorsement, recommendation, or favuring by the United States Government or any agency thereof. The views and opinions of authors expressed herein do not necessarily state or reflect those of the United States Government or any agency thereof. 
ORNL/Sub-7715/4

Contract No. W-7405-eng-26

\title{
OPERATING TEMPERATURES OF RECESSED FLUORESCENT \\ FIXTURES WITH THERMAL INSULATION
}

D. W. Yärbrough and I. A. Toör Department of Chemical Engineering Tennessee Jechnological University Cookeville, TN 38501

Subcontract 7715

Date Published: May 1981

Part of

The National Program for

Building Thermal Envelope Systems and Insulating Materials

Research sponsored by the Office of Buildings and Community Systems, Buildings Division

U.S. Department of Energy

\author{
OAK RIDGE NATIONAL LABORATORY \\ Oak Ridge, Tennessee 37830 \\ operated by \\ UNION CARBIDE CORPORATION \\ for the \\ DEPARTMENT OF ENERGY
}

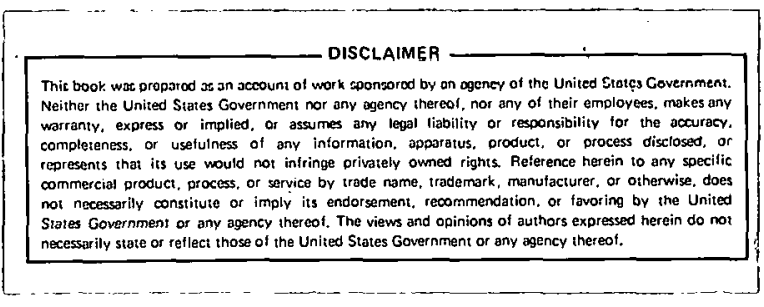




\section{FOREWORD}

This is one of a series of reports to be published describing research, development, and demonstration activities in support of the National Program for Building Thermal Envelope Systems and Insulating Materials. The National Program involves several federal agencies and many other organizations in the public and private sectors who are addressing the national objective of decreasing energy wastes in the heating and cooling of buildings. Results described in this report are part of the National Program through delegation of management responsibilities for the DOE lead role to the Oak Ridge National Laboratory.

Ted S. Lundy

Program Manager

Building Thermal Envelope Systems and Insulating Materials

Oak Ridge National Laboratory

E. C. Freeman.

Program Manager Buildings Division Office of Buildings and Community Systems

Department of Energy 
REPORTS - BTESIM PROGRAM

1. DOE/CS-0059: The National Program Plan for Building Thermal Envelope Systems and Insulating Materials (January 1979).

2. LBL-8822: A New Measurement Strategy for In-Situ Testing of Wal1 ThermaT Performance (March 1979).

3. LBL-8925: Thermal Performance of Buildings and Building Envelope Systems: An Annotated Bibliography (March 1979).

4. ORNL/SUB-7556/I: Assessment of the Corrosiveness of Cellulosic Insulating MateriaTs (June 1, 79 ).

5. ORNL/SUB-7504/3: Recessed Light Fixture Test Facility (July 1979).

6. ORNL/SUB-7559/I: Problems Associated with the Use of UreaFormal dehyde Foam for Residential Insulation (September 1979).

7. ORNL/Sub-7551/I: Interim Progress Report on an Investigation of Energy Transport in Porous Insulator Systems (October 1979).

8. ORNL/TM-6494: A Technique for Measuring the Apparent Conductivity of Flat Insulations (October 1979).

9. LBL-9821: Measurement of In-Situ Dynamic Thermal Performance of Building Envelopes Using Heat FTow Meter Arrays (December 1979).

10. ORNL/Sub-79/13660/I : Minnesota Retrofit Insulation In Situ Test Program Extension and Review (February 1980).

11. ORNL/TM-7266: An Experimental Study of Thermal Resistance Values (R-Values) of Low-Density Mineral-Fiber Building Insulation Batts tommerciatly Available in 1977 (Aprit 1980).

12. NBS/BS Series 123: The Effect of Moisture on the Thermal Conductance of Roofing Systems (ApriT 1980).

13. ORNL/Sub-78/97726/I : A FieTd Study of Moisture Damage in Walls Insulated Without a Vapor Barrier (May 1980).

14. ORNL/CON-46: An Appraisal of the M Factor and the Role of Building Thermal Mass in Energy Conservation (JuTy 1980).

15. ORNL/Sub-7686/I: Smoldering Combustion Hazards of Thermal Insulation Materials (July 1980).

16. NBSIR 80-2097: Precision Measurements on Fibrous Glass Insulation (July 1980). 
17. NBSIR 80-2085: Fire Performance of Loose-Fill Cellulosic Insulation in Residential Occupancies (August 1980).

18. ORNL/Sub-7556/2: Corrosion Testing of Urea-Formaldehyde Foam Insulating MateriaTs (September 1980).

19. NBSIR 8:-2100: Thermal Resistance Measurements of a Built-Up Roof System (October 1980).

20. NBSIR 80-2129: Modeling for Determination of Temperatures of Electrical Cables Within Thermally Insulated Walls (October 1980).

21. ORNL/CON-61: An Experimental Plan for Investigating BuildingEarth Heat Transfer at the Jolnt Instllute for Hedvy-Iun Research Building (December 1980). .

22. ORNL/Sub-7715/1: Operating Temperatures for a Convectively Cooled Recessed Incandescent Light Fixture (herember 1980).

23. ORNL/TM-7481: Analysis of Heat Transfer in Building Thermal Insulations (December 1980).

24. ORNL/tr-4679: Roofing Felt on Polystyrene (December 1980).

25. STP-718: Proceedings of ASTM/DOE Thermal Insulation Conference, Tampa, Florida, October 1978 (December 1980).

26. ORNL/Sub-7559/3: Problems Associated with the Use of UreaFormaldehyde Foam for Residential Insulation: Part III: Residential Studies in CoTorado and Wisconsin (February I98i).

27. ORNL/Sub-7559/4: Problems Associated with the Use of UreaFormaldehyde Foam for Residential Insulation. Part IV: The Relevance of Materials Standards to Problems As soclated with the Use of Urea-Formaldehyde Foam InsuTation (February 1981).

28. ORNL/Sub-7559/2: Problems Associated with the Use of UreaFormaldehyde Foam for Residential Insulation. Part II: The Effects of Temperature and Humidity on Free Formaldehyde, Extractable Formaldehyde, Formaldehyde Emission and Physical Characteristics of the Foam (February 1981).

29. NBSIR 81-1639: Effective Thermal Conductivity of a Glass Fiberboard Standard Reference Material (February 1981).

30. NBSIR 81-1640: Effective Thermal Conductivity of a Glass Fiberblanket Standard Reference Material (February 1981).

31. ORNL/TM-7629: Roofing Research - A Bibliography (Apri1 1981). 


\section{SUMMARY}

Test results are given in this report for steady state operating temperatures for two recessed fluorescent fixtures of the type used in commercial or industrial applications. The fixtures were operated at power levels at or below the design value with and without thermal insulation installed above the fixtures.

The tests showed that thermal insulation above the fixtures resulted in temperatures sufficiently high to activate the heat switches in the ballasts with resultant intermittent operation. All observed temperatures were below $30^{\circ} \mathrm{C}$. Satisfactory performance of fluorescent fixtures covered with thermal insulation will require minor changes in either the design or location of the ballasts which are the primary heat source. An uninsulated space above the area containing the ballasts permitted sufficient cooling to maintain ballast temperatures low enough for continuous operation. 
THIS PAGE

\section{WAS INTENTIONALLY LEFT BLANK}




\section{OPERATING TEMPERATURES OF RECESSED FLUORESCENT}

FIXTURES WITH THERMAL INSULATION

\section{Introduction}

The installation of thermal insulation above ceilings in commercial or industrial buildings is one of many energy conservation acts commonly considered. In many cases attention must be given to existing electrical systems and lighting fixtures as the installation of thermal insulation is specified. Previous reports in this series ${ }^{1,2}$ have dealt with the operation of recessed fixtures with incandescent lamps with and without thermal insulation around the attic side of the fixture. Results are given in this report for observed temperatures for two recessed fluorescent fixtures of the type currently in use. The two fixtures were instrumented with thermocouples and operated at or below the design power levels by disconnecting one or more of the tubes. The first fixture tested had been in place in a dropped ceiling for over five years. The second fixture was new. It was mounted in a rectangular wooden frame and placed approximately $0.6 \mathrm{~m}$ (24 inches) above the laboratory floor.

The purpose of the present study was to determine steady state surface temperatures for recessed fluorescent fixtures operated with and without thermal insulation on the top side of the fixture and identify potential problems associated with the installation of thermal insulation. In addition to measuring temperatures, means were sought by which the fixtures can be thermally insulated and operated without fire hazards or damage to the fixture.

Fluorescent tubes operate at lower temperatures than corresponding wattage incandescent lamps. Fixtures for fluorescent tubes, however, include one or more "ballasts" to provide the voltage needed for fluorescent 
tube operation. The ballasts represent heat sources within the fixture and in addition typically contain a thermal switch which opens the power circuit with overheating.

\section{Test Prócedure}

The measurement of fixture surface temperatures was accomplished by mechanically attaching copper-constantan thermocouples to the surtaces using machine screws. The thermocouples were read relative to a $0^{\circ} \mathrm{C}$ ice bath using a digital voltmeter ${ }^{3}$. Steady.state temperatures for a given operating configuration were determined by keeping the fixture powered until all of the surface temperatures being monitored were constant to within $\pm 0.1^{\circ} \mathrm{C}$ for at least 30 minutes. The ambient temperature in a11 cases was in the interval $20-28^{\circ} \mathrm{C}$. The tested fixtures were operated with the design number of fluorescent tubes in place and with tubes removed. No attempt was made to overpower the fixtures.

Temperature data for two recessed fluorest:enl. Fixlures were collected in this study. The first, designated fixture $A$, was installed in a dropped ceiling that is suspended from a concrete pad. Fixture $A$ was at a standard height of eight feet above the floor in an office. The second recessed fixture, identified as fixture $B$, was installed in a wooden frame $0.95 \mathrm{~m}$ ( 45 inches) wide, $1.75 \mathrm{~m}$ (69 inches) long, and $0.23 \mathrm{~m}$ ( 9 inches) deep. The bottom of the box was fabricated from $13 \mathrm{~mm}(.5$ inch) sheetrock to simulate a ceiling. The frame containing fixture $B$ was positioned on wooden supports $0.6 \mathrm{~m}$ ( 24 inches) above the laboratory floor. The two fixtures were instrumented as shown in Figures 1 and 2 . Five thermocouples were attached to the attic-side surface of fixture $B$. A single thermocouple was also attached to the surface of one of the fluorescent tubes in fixture $B$. Dimensions and label information for the two 
ORNL-DWG. 81-10265

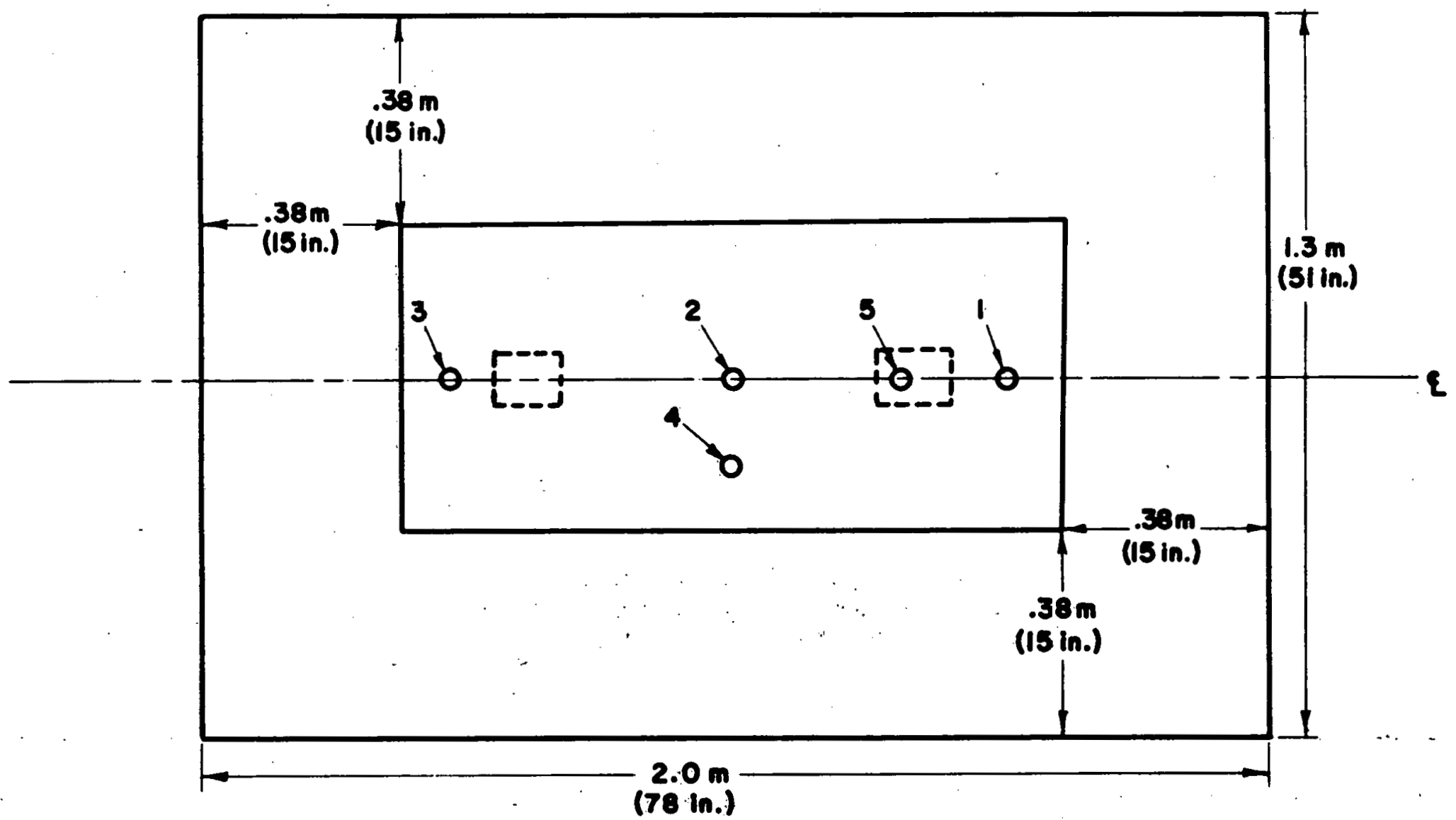

(a) NUMBEREo CIRCles ARE tHERMOCOUPLE locations

(b) DASHED RECTANGLES INOICATE BALLAST LOCATIONS

(c) SMALL SOLID RECTANGLE IS FIXTURE

(d) LARGE SOLID RECTANGLE IS EXTENT OF INSULATED AREA

-FIGURE I: DIAGRAM OF FIXTURE a INSTRUMENTATION 
ORNL-DWG. B1-10266

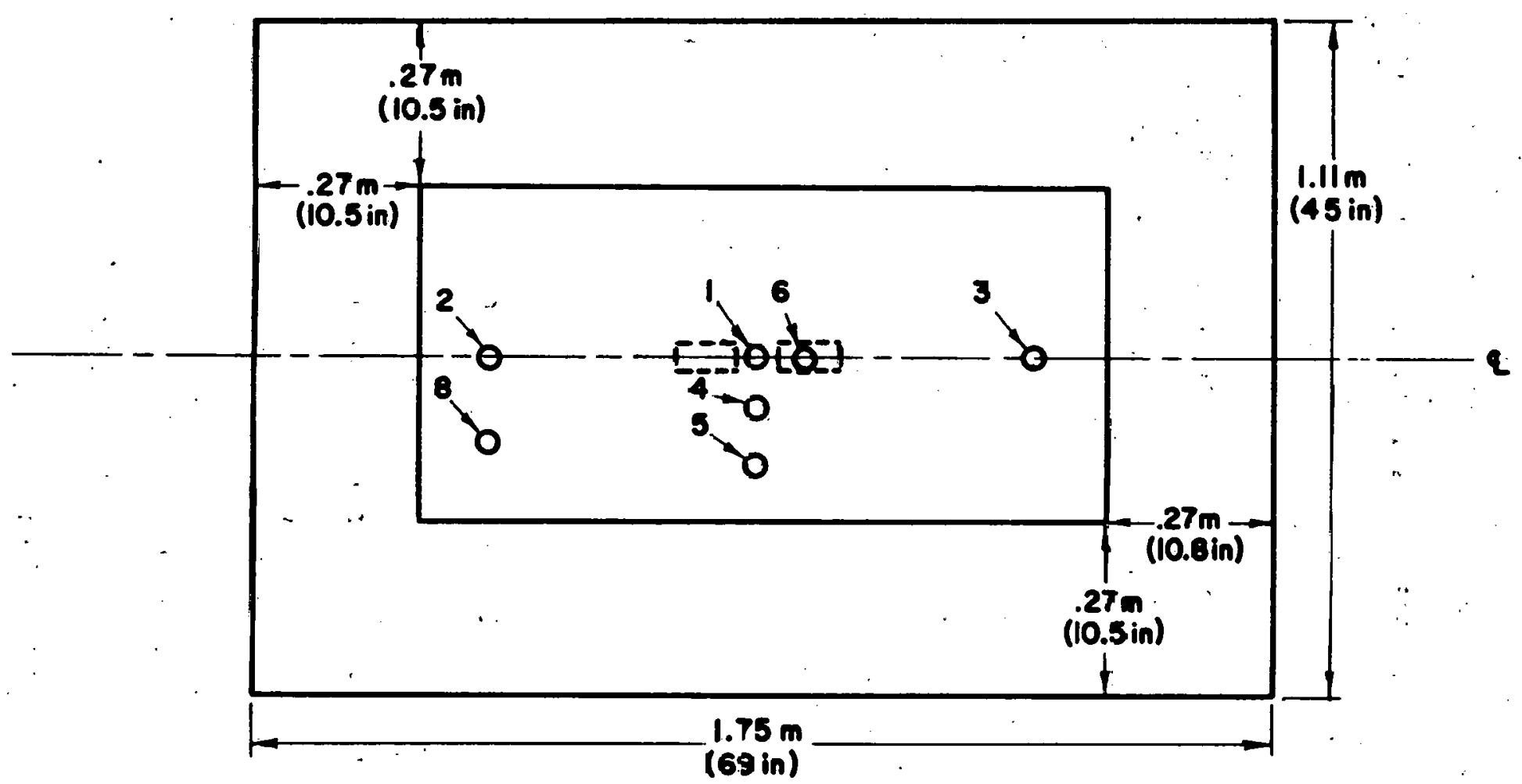

(o) NUMBERED CIRCLES ARE THERMOCOUPLE LOCATIONS

(b) DASHED RECTANGLES ARE BALLAST LOCATIONS

(c) SMALL SOLID RECTANGLE IS FIXTURE:

(d) LARGe SOLID RECTANGLE IS frame: CONTAINING MISUlation

FIGURE 2: DIAGRAN OF FIXTURE B INSTRUMENTATION 
fixtures is given in reference notes 4 and 5 .

Fixture $A$ is equipped with two ballasts and is designed for use with three 40 watt fluorescent tubes. The thermally uninsulated fixture was operated with one, two, or three tubes in place to determine the normal range of operating temperatures for the fixture. The fixture was then thermally insulated on the top side with fiberglass batts cut to form thermal barriers $0.38 \mathrm{~m}$ ( 15.0 inches) thick on the sides and $0.18 \mathrm{~m}$ (7 inches) or $0.28 \mathrm{~m}$ (11 inches) thick on the top. A cross-sectional view of the fixture and insulation appears in Figure 3. Fixture $A$ was operated with the ceiling side cover partially or totally removed in addition to standard operation with the cover in place.

Fixture $B$ is also equipped with two ballasts and is designed for use with four 40 watt fluprescent tubes. The fixture was wired in such a way that it can be operated with either two or four tubes powered. The wooden frame containing fixture $B$ was filled to a depth of $0.25 \mathrm{~m}$ (10 inches) of loose-fill rock wool insulation at a density of $36.8 \mathrm{~kg} / \mathrm{m}^{3}\left(2.3 \mathrm{ib} / \mathrm{ft}^{3}\right)$ for study of the fixture under thermal insulation. Fixture $B$ was also operated with the ceiling side cover open and closed. One series of measurements were illace with an open ended wooden frame $0.15 \mathrm{~m}$ by $0.43 \mathrm{~m}$ ( 6 inches by 17 inches) centered on top of the thermally insulated fixture to provide an air space for convective cooling. A photograph of the top side of the fixture with the frame in position is shown in Figure 4.

Steady state voltage readings from the thermocouple circuits were converted to temperatures using standard tables ${ }^{(6)}$. The thermocouples were checked against a mercury-in-glass thermometer at room temperature to make sure that they were not damaged in installation. Temperature measurements are believed to be accurate to within $\pm 1^{\circ} \mathrm{C}$. Electrical current through fixture $A$ was measured with an $A-C$ clamp-on Volt-Ammeter! $(7)$ 
ORNL-DWG. $81-10267$

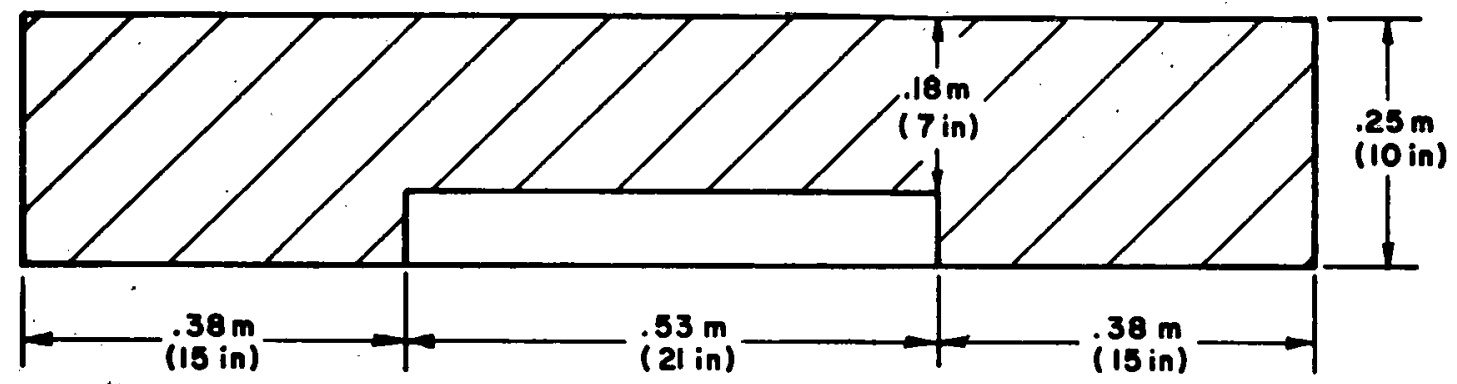

CONFIGURATION I

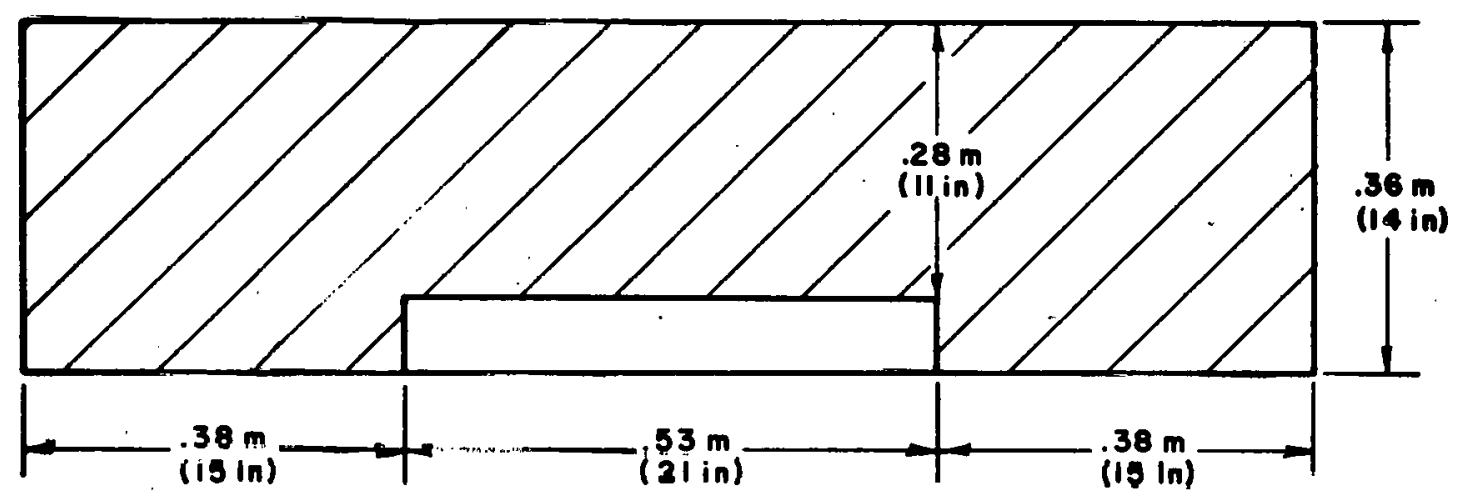

CONFIGURATION II

(0) SMALL SOLID RECTANGle is FIXTURE

(b) LARGE SOLID RECTANGLE SHOWS EXTENT OF INSULATION

FIGURE 31 ARRANGEMENT OF THERMAL INSULATION

AROUND FIXTURE A 

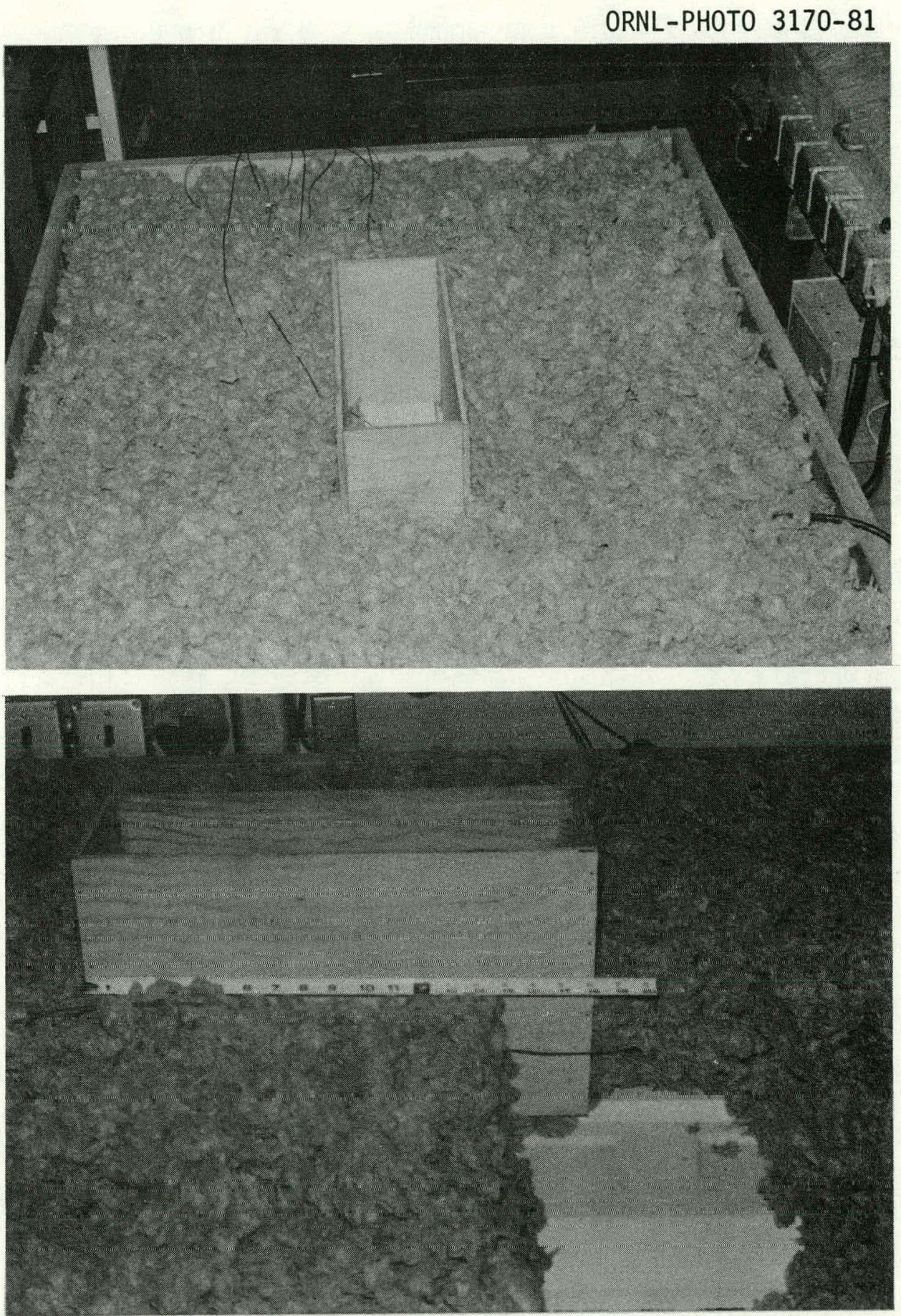

Figure 4: Fixture B with Thermal Insulation Barrier in Place. Total Insulation Thickness Shown is $250 \mathrm{~mm}$ (10 inches) with $178 \mathrm{~mm}$ (7 inches) above the Fixture. 
Electrical input to fixture B was monitored with an A.C. wattmeter (8). No unusual power variations were noted during the tests. Discussion of Results

Temperatures on the surface of fixture $A$ for twelve modes of operation are given in Table 1. It was observed that fixture surface temperatures of $78-80^{\circ} \mathrm{C}$ reflect internal ballast temperatures sufficient to open the power circuit. Consequently, temperature entries in Table 1 of $78-80^{\circ} \mathrm{C}$ indicate intermittent operation of the fixture. Cooling times in excess of one hour were required to return the fixture to operation after the thermal switch was activated. The internal temperatures of the ballasts were not measured but are certainly higher than the fixture surface temperatures. Operations of fixture $\mathrm{A}$ near $30^{\circ} \mathrm{C}$ resulted in a liquid dripping from the ballasts which would no doubt cause an early failure.

The maximum surface temperature recorded for fixture $A$ operated without thermal insulation was $43^{\circ} \mathrm{C}$ or approximately $20^{\circ} \mathrm{C}$ above the surroundings. Lower temperatures were observed when one or two of the tubes were taken out of operation. Observed surface temperatures for fixture A were increased by placing fiberglass batts above and around the attic side of the fixture. The fixture temperatures approached the "cut-out" value when insulated with $0.18 \mathrm{~m}$ ( 7 inches) of fiberglass insulation. The operation of the fixture was intermittent with $0.28 \mathrm{~m}$ (11 inches) of fiberglass insulation and three tubes powered. The data in Table 1 show that opening the ceiling side cover or removing one tube from the fixture resulted in a drop in temperature to a level where continuous operation of the thermally insulated fixture was possible. The data in Table 1 reflect operation with minimal air movement on the room side of the fixture. It was observed that air movement resulting for example by room ventilation caused a decrease in operating temperatures. Figure 5 contains temperature data plotted against fixture power for operation of fixture A with 
TABLE 1

Operating Temperatures for Fluorescent Fixture A

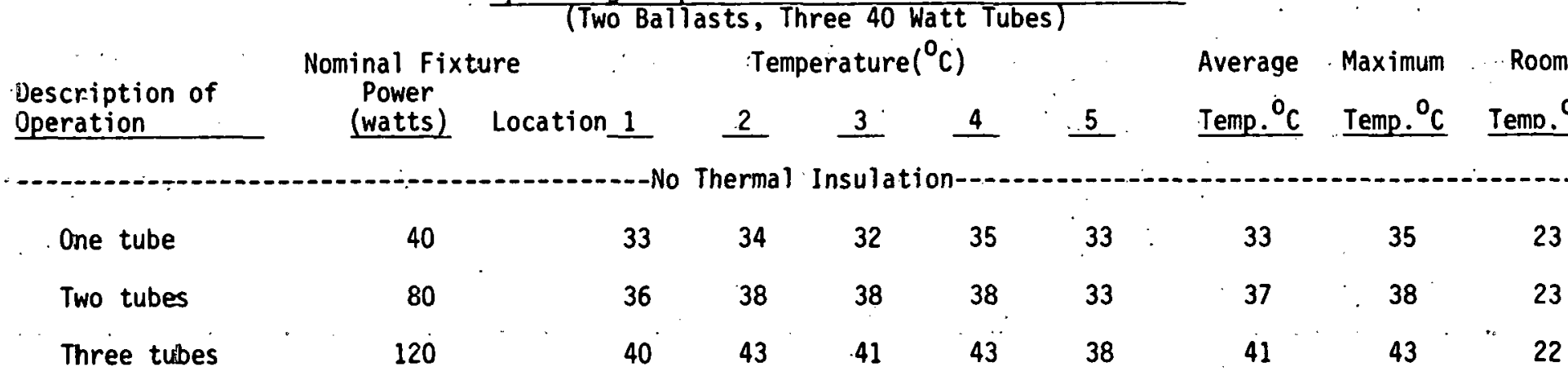

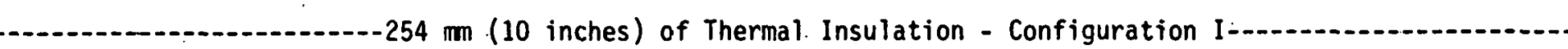

$\begin{array}{lrrrrrrrrr}\text { One tube }{ }^{(a)} & 40 & 47 & 48 & 45 & 50 & 46 & 47 & 48 & 23 \\ \text { Two tubes } & 80 & 53 & 57 & 57 & 57 & 50 & 55 & 57 & 25 \\ \text { Three tubes } & 120 & 67 & 70 & 67 & 72 & 64 & 68 & 72 & 25\end{array}$

$-356 \mathrm{~mm}$ (14 inches) of Thermal Insulation - Configuration II

\begin{tabular}{|c|c|c|c|c|c|c|c|c|}
\hline Three tubes & 75 & 79 & 75 & 80 & 72 & 76 & 80 & 26 \\
\hline with ballast cover open & 74 & 78 & 74 & 78 & 70 & 75 & 78 & 26 \\
\hline and fixture cover open & 62 & 66 & 62 & 67 & 58 & 63 & 67 & 28 \\
\hline $\begin{array}{l}\text { with ballast cover closed } \\
\text { and fixture cover open (a) }\end{array}$ & 61 & 65 & 61 & 67 & 58 & 62 & 67 & \\
\hline $\begin{array}{l}\text { and } 50 \% \text { of fix.ture } \\
\text { cover removed }\end{array}$ & 68 & 73 & .68 & 74 & 64 & 69 & 74 & 25 \\
\hline $\begin{array}{l}\text { and } 25 \% \text { of fixture } \\
\text { cover removed }\end{array}$ & 75 & .79 & 75 & 80 & 72 & 76 & 80 & 25 \\
\hline
\end{tabular}

(a) Average for two sets of data. The maximum temperature shown is the maximum individual reading. 


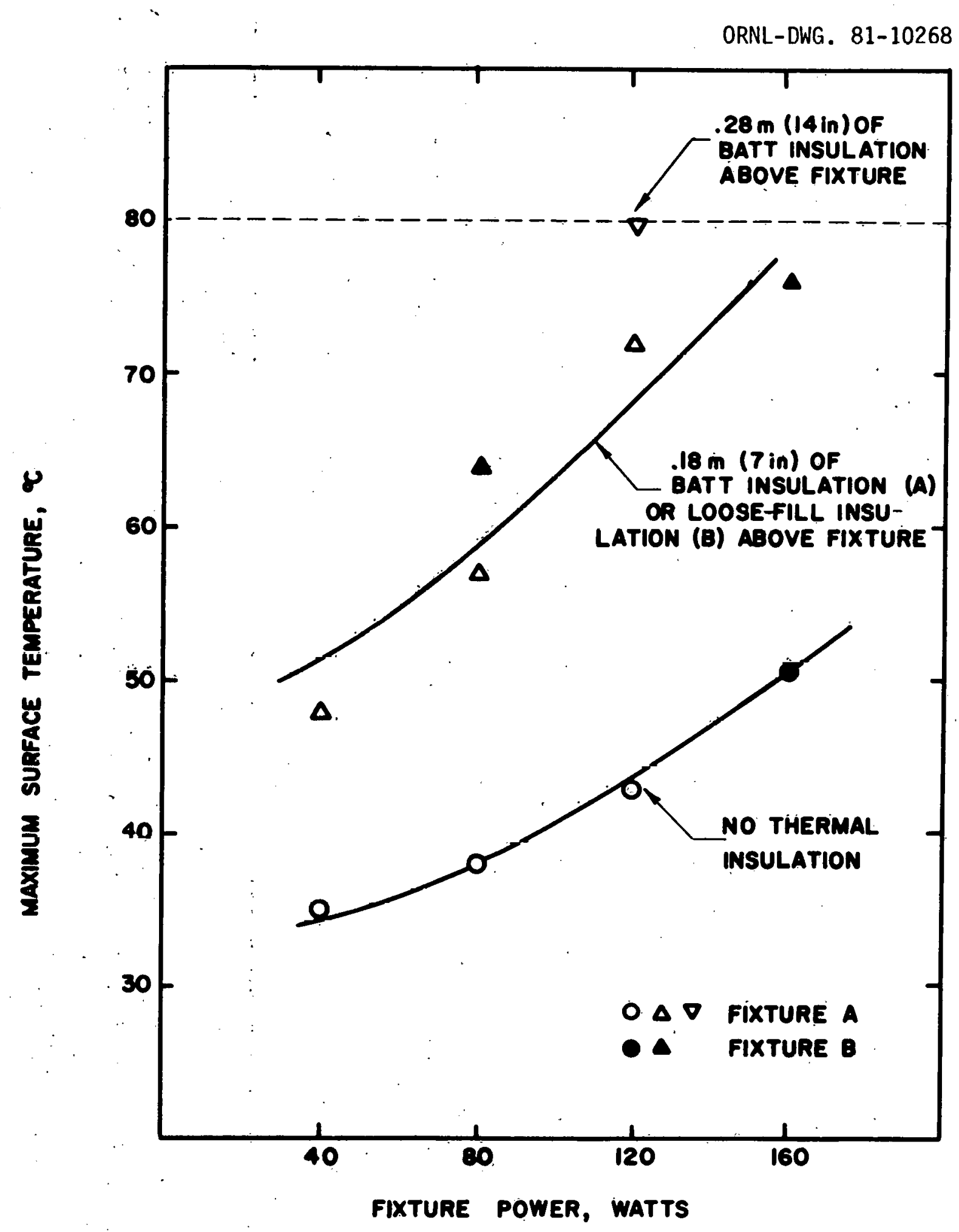

FIGURE 5. RECESSED FLUORESCENT FIXTURES OPERATED WITH AND WITHOUT THERMAL INSULATION 
the cover closed.

Surface temperatures for fixture B are given in Table 2. The insulation of fixture B with a total depth of $0.25 \mathrm{~m} \cdot(10$ inches) of rock wool, resulted in temperatures near the limit for continuous operation with four tubes. The insulation above the fixture was approximately R-21. The data in Table 2 show that the temperature of thermally insulated fixture $B$ is lowered by opening the fixture cover. The operating temperature of the fixture can also be lowered by not covering a relatively small area on the top of the fixture. Operation of fixture B with an uninsulated area $0.15 \mathrm{~m}$ by $0.43 \mathrm{~m}$. ( 6 inches by 17 inches) above the ballasts resulted in an average surface temperature only ten degrees above that recorded for the fixture operated without thermal insulation. Temperature data for fixture B are also shown in Figure 5.

A thermocouple was banded to one of the fluorescent tubes in fixture $B$ and tube surface temperatures were monitored and recorded as location 7 in Table 2. The tube temperatures were less than or equal to the maximum recorded fixture temperature in every case. The baliasts rather than the tubes are the primary heat source in the fixture. The fact that the fluorescent tubes operate at a lower temperature than incandescent bulbs accounts for the observation that opening the ceiling side cover has minimal effect on the fixture operating temperature. The fluorescent tubes are not hot enough to produce significant air movement through the fixture. Surface temperatures for incandescent bulbs are strongly dependent on the ambient conditions, air flow around the bulb, and the positioning of the bulb in a fixture. A few surface temperatures for a 75 watt incandescent bulb in a closed fixture were measured by strapping a thermocouple to the surface of the bulb. Temperatures in excess of $200^{\circ} \mathrm{C}$ were recorded. 


\section{TABLE $\approx$}

Operating Temperatures for Fluorescent Fixture B (Two Eallasts, Four 40 Watt Tubes)

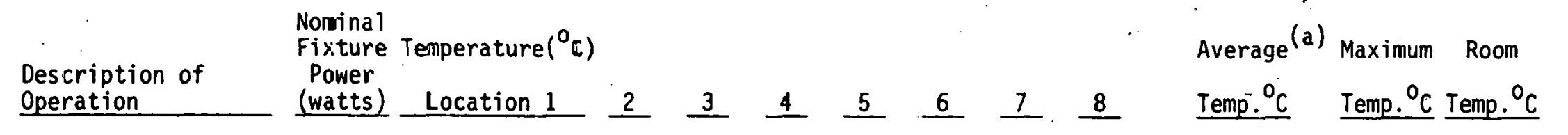

Insulation

Four tubes

160

$45 \quad 50$

50

49

$51 \cdot 24$

(10 inches) of Loose-Fill Rock wool-

Two tubes 80

Four tubes 160

$\begin{array}{lll}\text { 58. } & 63 & 62 \\ 72 & 75\end{array}$

62

$51 \quad 63$

$3 \quad 5$

$\begin{array}{lll}3 & 53 & 64 \\ 6 & 61 & 76\end{array}$

$49 \cdot 54$

5454

fixture cover open 80

Four tubes and

fixture cover open 160

$\begin{array}{llllllll}59 & 66 & 66 & 64 & 66 & 56 & 55 & 68\end{array}$

64

$\begin{array}{lll}61 & 64 & 23 \\ 73 & 76 & 23\end{array}$

Fixture Insulated with $254 \mathrm{~mm}$ (10 inches) of Loose-Fill Rock Wool (6 inches $x 17$ inches). Barrier in P1ace

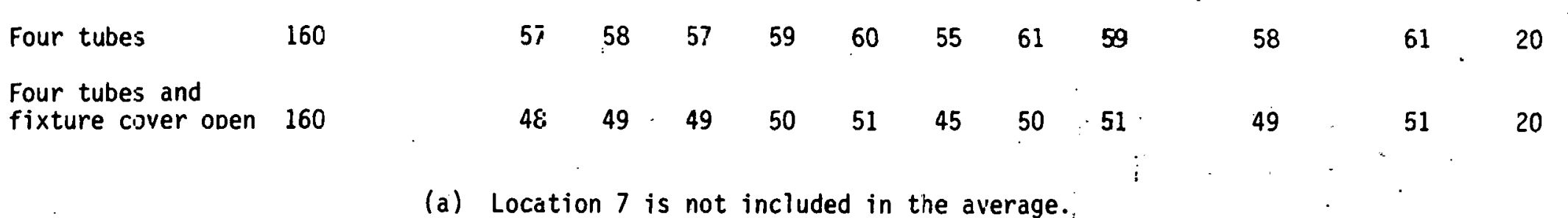

Thermocouple 7 was attached to the surface of one of the tubes in the fixture." 


\section{Conclusions and Recommendation}

The thermal cut-out present in fixture $A$ prevented operating temperatures above $80^{\circ} \mathrm{C}$. Thermal insulation of the fixtures resulted in temperatures that approached the $80^{\circ} \mathrm{C}$ limit. The operation of fixture $A$ with thermal insulation resulted in temperatures sufficient to melt the wax present in the ballast. A redesign of recessed fluorescent fixtures with special attention given to the location of the ballasts should be undertaken so that the fixtures can be thermally insulated. Consideration should be given to a ballast redesign which would result in less heat generation and improved heat dissipation. Existing fixtures can be insulated if the tops are left uncovered. The findings of this laboratory study are summarized below.

0 The inclusion of thermal switches in fluorescent fixtures prevent them from being a fire hazard when covered with thermal insulation.

O Existing ballasts can be damaged by the higher operating temperatures that accompany therma 1 insulation of the fixtures.

O Operating temperatures of thermally insulated fluorescent fixtures can be lowered to levels which will not result in damage by leaving part of the top of the fixture uninsulated.

O Operation of thermally insulated fluorescent fixtures with the ceiling side cover open did not result in strong convective cooling because the tubes operate relatively cool. 
References and Notes

1. Yarbrough, D. W., K. T. Yoo and P. B. Koneru, "Recessed Light Fixture Test Facility", ORNL/SUB-7504/3, Oak Ridge National Laboratory, July, 1979.

2. Yarbrough, D. W., and I. Toor, "Operating Temperatures for a Convectively Cooled Recessed Incandescent Light Fixture", ORNL/SUB-7715/1, Oak Ridge National Laboratory, December, 1980.

3. Hewlett Packard 3405A Digital Voltmeter with stated accuracy $\pm(2 \mu \mathrm{V}$ $+0.03 \%$ of reading).

4. Fixture A was manufactured by Thomas Industries, Inc., Sparta, Tennessee. Recessed type light fixture issue No. A-24-305. UL listed. FixLure has lwu ballasts and is designed for thrce 10 watt tuber.

5. Fixture $B$ was manufactured by Lithonia Lighting, Cochran, Georgia. Recessed type light fixture issue No. A-196-260. UL listed. Cat. Number: 2GL 44C A12, 412768, Series II. Fixture has two ballạsts and is designed for four 40 watt tubes.

6. Thermocouple Reference Tables Based on the IPTS-68, NBS Monograph 125, March, 1974.

7. Weston Model $633 \mathrm{~A}-\mathrm{C} \mathrm{Cl}$ amp-on Volt-Ammeter with range 0-25 amperes.

8. A.C. Wattmeter manufactured by Weston Electrical Instrument Corp. with range $0-250$ watts. 
ORNL/Sub-7715/4

INTERNAL DISTRIBUTION

1-2. Central Research Library

3. Document Reference Section

4-5. Laboratory Records

6. Laboratory Records, ORNL RC

7. ORNL Patent Office

8-32. M\&C Division Office

33. R. S. Carismith

34. P. T. Carlson

35. K. W. Childs

36. G. E. Courville

37. F. A. Creswick

38. R. G. Donnelly

39. C. S. Dudney

40. W. Fulkerson

41. M. Guthrie

42. W. W. Harris

43. D. R. Johnison
44. T. S. Lundy

45. M. C. Matthews

46. D. L. McE Iroy

47: J. W. Michel

48. R. E. Minturn

49. J. N. Robinson

50. M. W. Rosenthal

51. T. F. Scanlan

52. A. C: Schaffhauser

53. J. 0. Stiegler

54. J. R. Weir, Jr.

55. R. L. Wendt

56-65. D. W. Yarbrough

66. A. Zucker

EXTERNAL DISTRIBUTION

67. P. R. Achenbach, 1322 Kurtz Road, McLean, VA

68. J. Adams, Lawrence Berkeley Laboratory, Berkeley, CA

69. R. W. Anderson, 7090 Tecumseh Lane, Chanhassen, MN

70. E. L. Bales, DOE/BCS, Washington, DC

71. J. Barnhart, TIMA, Mt. Kisko, NY.

72. A. L. Berlad, State University of New York, Stony Brook, NY

73. J. J. Boulin, DOE/BCS, Washington, DC

74. W. Brenner, National Institute of Building Sciences, Washington, DC

75. J. Cable, DOE/BCS, Washington, DC

76. S. H. Cady, MIMA, Summit, NJ

77. W. Carrol1, Lawrence Berkeley Laboratory, Berkeley, CA

78. T. Castino, Underwriters Laboratory, North Brook, IL

79. A. Castle, CPSC, Washington, DC

80. H. I. Cohen, CPSC, Washington, DC

81. R. W. Cole, New Mexico Energy Institute, Albuquerque, NM

82. S. Davis, National Bureau of Standards, Gaithersburg, MD

83. M. W. Dizenfeld, HUD, Washington, DC

84. R. S. Dougall, University of Pittsburgh, Pittsburgh, PA

85. W. Edmounds, Owens Corning Fiberglas, Washington, $D C$

86. W. P. Ellis, H. B. Fuller, Co., Spring House, PA

87. A. E. Fiorato, Portland Cement Association, Skokie, IL 
88. C. W. Frank, University of Iowà, Oakdale, IA

89-98. E. C. Freeman, DOE/BCS, Washington, DC

99. L. S. Galowin, National Bureau of Standards, Washington, DC

100. B. F. Gilmartin, Owens-Corning Fiberglas, Washington, DC

101. S. B. Glickman, Lightolier, Inc., Jersey City, NJ

102. L. R. Glicksman, MIT, Cambridge, MA

103. D. Goldenburg, TRW, Inc., Oak Ridge, TN

104. F. A. Govan, Brushwood Road, Stamford, CT

105. A. Greenburg, Geo-Energy Ltd., Port Jervis, NY

106. R. F. Hemphi.11; TVA, Chattanooga, TN.

107. C. Hollowe11, Lawrence Berkeley Laboratory, Berkeley, CA

108. J. G. Hust, National Bureau of Standards, Boulder, CO

109. R. R. Jones, National Bureau of Standards, Gaithersburg, MD

110. W. Kleinfelder; Underwriters Laboratories, Inc., Northbrook, IL

111. W. M. Kroner, Reirsselaer Polytechnic Institute, Truy, NY

112. R. A. Lacrosse, CIMA, Elk Grove Village, IL

113. L. E. LaFehr, International Assoc. of Electrical Inspectors, Park Ridge, IL

114. D. Larib, TVA, Chattanooga, TN

115. N. W. Lane, Lane Instruments, El Cajon, CA

116. S. Launey, DOE/BCS, Washington, DC

117. E. Lisee, ACEC Research \& Management Foundation, Washington, DC

118. K. R. Long, University of Iowa, Iowa City, IA

119. J. C. McGee, Tennessee Technological University, Cookeville, TN

120. J. T. Miller, GSA, Washington, DC

121. W. V. Miller, Civil Engineering Laboratory, Port Hueneme, CA

122.. J. P. Mitilnone, DOE/BCS, Washington, DC

123. D. E. Morgenroth, Owens-Corning Fiberglas, Toledo, $\mathrm{OH}$

124. L. Mulligan, CPSC, Washington, DC 20207

125. W. R. Newturl, TVA, Chattanooga, TN

126. T. J. Onlemiller, National Bureau of Standards, Baithersburg, MD

127. R. L. Parks, Underwriters Laboratories, Inc., Northbrook, IL

128. F. J. Powel1, National Bureau of Standards, Gaithersburg, MD

129. A. Rodin, American Home Lighting Institute, Chicago, IL

130. J. M. Roehm, PO Box 887, Virginia Beach, V.A

131. H. D. Ross, DOE/BCS, Washington, DC

132. T. Ryan, National Electrical Manufacturers Assoc.. Washington, DC

133. E. Schaffer, Forest Products Laboratory, Madison, WI

134. S. Selkowitz, Lawrence Berkeley Laboratory, Berkeley, CA

135. M. Shahin, CERL, Champaign, IL

136. M. Sherman, Jim Walters Research Corporation, St. Petersburg, FL

137. C. J. Shirtliffe, Natinnal Research Council, Ottawa, Canada

138. M. K. Snyder, Butler Mfg., Co. Research Center, Grandview, MO

139. R. Sonderegger, Lawrence Berkeley Laboratory, Berkeley, CA

140. E. Stamper, New Jersey Institute of Technology, Newark, NJ

141. J. R. Tanck, DOE/BCS, Washington, DC

142. G. J. Tettsma, Dow Chemical Company, Granville, $\mathrm{OH}$

143. Thomas Industries, Louisville, KY

144. C. L. Tien, University of California, Berkeley, CA

145-154. I. Toor, Tennessee Technological University, Cookeville, TN

155; G. A. Tisongas, Pontlland State University, Portland, OR 
156. R. P. Tye, Fiber Materials, Inc., Biddeford, ME

157. C. R. Vander Linden, Johns-Manville Sales Corporation, Denver, Co

158. J. D. Verschoor, Johns-Manville R\&D Center, Denver, CO

159. R. Viau,. Product. Safety Branch, Place Du Portage, Ottawa, Canada

160. S. S. Waddle, DOE/ORO, Oak Ridge, TN

161. R. Weil., Stevens Institute of Technology, Hoboken, $N J$

162. Office of Assistant Manager for Energy Research and Development, DOE/ORO, Oak Ridge, TN

163-240. Buildings Division Distribution List

241-267. Technical Information Center, PO Box 62, Oak Ridge, TN 37830 